\title{
Research on the Governmental Support of Education Reform and Development Need
}

\author{
Xiaolong Li \\ School of Fashion Engineering, Jiangxi Institute of Fashion Technology, Nanchang 330102, China \\ 576816683@qq.com
}

Keywords: Education reform; Central government coordination support; Inter-governments support; Inter-departments support; Partner relationship

\begin{abstract}
Governmental support is the key to the successful education reform and development. Three types of deficiencies exist in the education reform support system, which are demonstrated as the in-coordination of the overall support from central government, the reluctance of inter-governments support, and the lack of inter-department support. Structural game, the double temptation of cross game, and the interest supremacist in departments are the major causes of such deficiencies. Partnership between governments is an effective support of education reform and development in the future.
\end{abstract}

\section{Introduction}

Today's private higher education faces serious challenges, including perceived low quality and low reputation, fierce competition within the private sector, and with the public sector and international forces, and difficulties in recruiting students [1]. The past education reform showed that education reform without governmental support were hard to reach factual success. However, the effect of governmental support was weakening to some extent if the support to the education reform was excessive or deficient. Therefore, the effect support from government is the key to reach the success for education reform. Education reforms come in two general types: access and quality reforms. Access reforms provide more educational opportunities, while quality reforms improve educational effectiveness [2]. Today, the concept of overall government is obscure and vague. The government that plays an important role in education reform may be central government, local government, certain department of government, or the relationship between the central government and local government, the relationship between government and other governments, the relationship between departments and departments in government. In the content of government support, it may be policy support, system support, and finance support or the double support from policy and system, even ternary support from policy, system and finance. According to the country structure and the regime pattern, the government support that affects education reform and development in our country contains central government coordination support, inter-governments support and inter-departments support. Among them, central government coordination support is the longitudinal axis in government support of education reform; inter-governments support is lateral axis and inter-departments support is the net connecting shaft. put the status of government support deficiencies as the start, the thesis discussed the reasons of government support deficiencies and put forward the ways to construct partner governmental relationship. How to maintain the existing performance and provide opportunities for students with different talents becomes the center of education reform [3].

\section{The Manifestation of Government Support Deficiencies to Education Reform and Development}

Globalization has increased economic competition within and between countries and the world's regions. Economic competitiveness is commonly seen as a valid index for judging a country's level of economic prosperity. Many recent large-scale education reforms have been justified by the urgent need to increase labor productivity and promote economic development and growth through 
expanded and improved education [4]. In our country, all rights belong to central government, and the local rights have the authorization attribute from central government. The local government exercises the power under the unities lead of central government. From the point of law and system, they are parallel relationship between local governments and governments, but the development level of local government is not balanced, and they have complicated relationship. The relationship between inter-governments and other inter-governments as the factual department are not simple, which not only refers to longitudinal hierarchy relationship but also lateral responsibility relationship. As for all kinds of education reform in our country, especially the education reform projects that paid much cost, obvious not success and no way going ahead, which are due to the overall support deficiencies of central-local governments, inter-governments and inter-departments.

Structural Game: Central Government In-coordination Support. In facts, in the rights connection from central government to the local government, the local governments are the entrusted agent of central government. During this time, the term of entrusted agent last for more time, the central points of governments game will become more, the possibility of local government away from the purpose and whole profit of the central government will get more chance. At present, there were many examples of reform fail or reform effects worse due to not clear responsibility, affair disorder and displacement of local and central government in education reform.

The Place Benefit Maximization: The Reluctance of Inter-governments Support. longitudinal inter-government relationship mainly possess political and administrative significance, and is a structural game of a dis-symmetry, then lateral local governments relationship possess economy significance, cultural significance and is a competition game based on the equal rights. Generally speaking, the competition between government and government happened in the same level government which were near in geography position, equal in economic strength, political effects similar and cultural development synchronization, and the aim is to obtain tangible or intangible resource. From the point of inter-governments coordination about education reform, the internal experience and exploration of local government were more, tackling the key problems together were less; the resource which was wasted was more, shared by others was less; again experiences were more than joint innovation.

Boundary Consciousness: The Lack of Inter-department Support. In the concrete context of education reform, different departments of governments are the most animateurs. All kinds of departments of governments are the units of carrying and operating of education reform, no matter the form was carried from down to up or by the local government. Therefore, the coordination between governments and governments has great significance. In detail, the coordination in our country political structure contains two types: one is the coordination of different departments in the equal governments; the other is the coordination different level governments. The former establishes piece to piece relationship, the later establishes strip to piece relationship.

\section{The Reason Analysis of Government Support Deficiencies to Education Reform and Development}

There are many reasons for the deficiencies of government support to education reform and development between central government coordination support, inter-governments support and inter-departments support. They not only have interest conflict but also the dis-symmetry of finances and affairs rights. Here we analyze the reasons from three aspects of the in-coordination of the overall support central government, the reluctance of inter-governments support, and the lack of inter-department support.

Central and Local Government Game: the Reasons Analysis to the Central Government Coordination Overall Support Deficiencies The relationship between central government and local government is not static although our country is centralization of one system nation. Since reform and opening, the central government and local government experienced cycle evolution from centralization to decentralization to centralization. Furthermore, the special zone and free trade zone 
policy, and the development concept of letting some people get rich first all made the relationship between central government and local government complicated. In democratic societies, it is becoming increasingly common for the government to formulate science education policies and programmers to reform education [5].

The Double Temptation of Cross Game: The Reasons Analysis to the Reluctance of Inter-governments Support. A certain scholar said that the double temptation is a reasonable frame to explain the relationship between government and government, because every government not only belongs to longitudinal competition sequence but also lateral competition sequence [6]. From the longitudinal aspect, the local government must obtain all kinds of resources, especially the rights resource and political achievement reward and chance of promotion; from the lateral aspect, the promotion capital of local government is not from the central government's grant, but the competition's outstanding with the parallel government. As an independent game unit, any action of local government based on its status, structure and desire, which was cross game and an ideal decision of longitudinal and lateral game.

Interest Conflict: The Reasons Analysis to the Lack of Inter-department Support. In education reform, some departments did not want to lose the profit that they have got, even desiring to obtain more through education reform. Department interest puts the department right as the premise and realizes this through the right's exclusiveness. To all appearances, all function departments of government were classified according to their rights and responsibility. If every department functions classification was decided,

The Berlin Wall was formed which was based on its function or specialization division. These walls block interior information and strangle external information. Every department desire to operate its rights incisively and vividly, furthermore, they must consider the production of rights; let the rights bring profit, expansion or colony, leading to the rights' omnipotence and omnipresence [7].

\section{Partner Government Relationship: Partnership between Governments is an Effective Support of Education Reform and Development in the Future}

Education reform encounters in-coordination of the overall support from central government, the reluctance of inter-governments support and the lack of inter-department support, whose resources lie in nation's political structure, the relationship between government and society, government and market. We must build partner government relationship if we want to reverse longitudinal and lateral governments in-coordination, the premise is to make nation and society operate smoothly and have clear responsibility and rights. From the point of logic, partner government relationship could provide method lead from four aspects: surpass grades, specify location, and negotiate dialogue and win-win cooperation. The government's governance logic must change from order mechanism of centripetal force and interest mechanism of dispersive mechanism to negotiation mechanism of bonding force, forming partner government relationship of equal dialogue, democratic participation and benign interaction to decline the harm to education reform.

Surpass Grades, De-administration. As we all know, the process of education reform in the government have clear grades and distinct limit, but the government's rights and responsibilities are chaos, buck-passing. The operators of reform spend much time in coordinating inter-government relationship, making the reform cost high. Therefore, we must adjust grade constraint and administrate limit to commence communication, equal dialogue and negotiation game. In fact, administrative ranks are a production by man-made. Therefore, when it severely hinders the success of education reform, and affects the realization to the government and society, we must radically reform and eliminate worship consciousness towards administrative levels.

Specify Orientation, Unify Rights and Responsibility. DE-administrative does not mean weakening government responsibility does even not mean the death of the government. On the contrary, we must specify the central government and local government's rights and responsibility through constitution; we must specify the local government's rights and responsibilities in detail 
through local organic law. Dating from China modern law history, some constitution was made to endow local governance. Today, when education reform could not go far because of the chaos of government's rights and responsibilities, the reluctance coordination, it is imperious for the relationship of government returning to law pathway of affairs and finances rights. Only the administrative relationship between governments was weakened, and the governance relationship was strengthened, education reform could obtain system support, policy support and finance support from all kinds of government.

Negotiate Dialogue, Practice Together. The construction of partnership between governments is a building and identification. When the governments reach the corporate consciousness, believing each other, sharing reputation, respecting each other and achieving the common goal provide social basis for equal cooperation. Of course, partnership between governments is an ideal pursuit; it is hard to be absorbed into government's actual action of equality, coordination and cooperation under the background of thousands of centralization. Our education reform need system support, policy support and finance support from By pledging to increase public expenditure on education and promote fair distribution of educational resources, the Medium- and Long-term National Educational Reform and Development Plan (2010-20) has laid a solid foundation for China top and down join, right and left coordination and inside and outside assort. In fact, any reform must depend on the system support from the government and partnership between governments. O develops into a powerhouse of human capital [8].

\section{Conclusions}

There are both temporal and socio-political dimensions to the idea of the university. On the one hand, the Government is investing heavily in the public sector. On the other hand, it is assisting the private sector by various means. However, there is a lack of systematic planning in the area of public-private partnership. There are also two issues which may hinder the current development of private higher education. They are an outdated legal. framework and a lack of standardized quality assurance measures [9]. On the one hand, the Government is investing heavily in the public sector. On the other hand, it is assisting the private sector by various means. However, there is a lack of systematic planning in the area of public-private partnership. There are also two issues which may hinder the current development of private higher education. They are an outdated legal. Framework and a lack of standardized quality assurance measures. With the progress of science and technology and the rise of the Internet, the network education has gradually come into people's sight. MOOC, as a new form of network education, has exerted an important influence on the Chinese higher education, and meanwhile, promoted the reform of higher education. Of course, our government attaches importance to it and makes every effort to do it well. Future reform attempts would have to begin with restructuring education away from a heavily-centralized and stated-run system, and towards competition and accountability, beginning with decisive de-centralization. As the global economy develops, the comprehensive strengths of all countries are getting increasingly reinforced. The international competition is constantly intensified. The ownership of high-quality and professional talents has become one of the key elements of whether a country takes the dominant position in the international competition. At present, the educational cause in China is continually adjusted and improved with the social development. The fine arts majors in higher normal colleges are training the future teachers for fine arts education. As globalization intensifies and economies struggle to address

'austerity' , educational reform continues unabated. In the case of initial teacher education (ITE) the pendulum swings between practice and research with a growing emphasis on teacher educators' expertise [10]. In the 21st century, when the universalization of higher education demands diversified students to be more involved in study and rather than in learning, the ideal of scholarship is expected to transform toward both teaching orientation and study orientation, which need our government change its governance, our teachers change our teaching ways and our students change our learn ways, in a word, we all need to do some reform and changes. It is argued that the difficulties in which the 
contemporary discourse about universities constantly becomes entangled, reflect more fundamental impasses and even contradictions that the modern democratic project is experiencing today[11]. Therefore, it is necessary to do some research on the relationship between the government and the university.

\section{References}

[1] Jing Lei, Striving for survival and success: Chinese private higher education in the twenty-first century, On the Horizon, 2012, Vol.20 (4), pp.274-283

[2] Vigile Marie Fabella, Political-economic determinants of education reform: Evidence om imterest groups and students outcomes, European Journal of Political Economy, 2016

[3] Tzu-Bin Lin, Li-Yi Wang, Jen-Yi Li, Chihming Chang, Pursuing Quality Education: The Lessons from the Education Reform in Taiwan, The Asia-Pacific Education Researcher, 2014, Vol.23(4), pp.813-822

[4] P. Sahlberg, Education Reform for Raising Economic Competitiveness, Journal of Education Changes, 2006, Vol. 7(4)

[5] Raja Panwar, john hoddinott, The influence of academic scientists and technologists on Alberta's secondary science curriculum policy and programme, International Journal of Science Education, 1995,Vol.17(4)

[6] Liu Zuyun, Inter-government Relationship: cooperation game and government governance, XUEHAI, 2007,(1)

[7] Wang Dahai, Wu Qunfang(Translation), No Gap Government, China People's University Press, 2002

[8] Information on http://www.en.ce.cn/National/Education/201006/23/t20100623_21540341.shtml

[9] Cheng Man Diana Lau, PongKau Yuen, Development of private higher education in Macau: Exploring the relationship between government and private sector, Frontiers of Education in China, 2010, Vol.5(3),PP. 450

[10] Jim Gleeson, Ciaran Sugrue, Joanne O'Flaherty, Research capacity and initial teacher education reform:Irish experiences, international perspectives, Teaching and Teacher Education, 2016

[11] Barbara Haverhals, The normative foundations of research-based education: Philosophical notes on the transformation of the modern university idea, Studies in Philosophy and Education,2007, Vol 26(5), PP.419 